\title{
SIKAP BAHASA WANITA KARIR DAN IMPLIKASINYA TERHADAP PEMERTAHANAN BAHASA JAWA DI WILAYAH YOGYAKARTA
}

\author{
Yayuk Eny Rahayu dan Ari Listiyorini \\ Fakultas Bahasa dan Seni Universitas Negeri Yogyakarta \\ e-mail: yayukeny@yahoo.co.id
}

\begin{abstract}
This study aims to describe perceptions, attitudes, and factors influencing the use of Javanese among career women and the implications for the Javanese preservation in the Yogyakarta area. It was a survey study involving working women whose mother tongue was Javanese. The data were collected through a questionnaire and were analyzed using the descriptive technique. The findings show that the career women's perceptions are still positive. This is supported by the fact that they use Javanese in informal communicative situations. They use it in the communication with husbands, children, servants, and community members in informal situations, and colleagues in the workplace. It can be concluded that in informal communicative situations there has been no significant shift from Javanese into Indonesian among career women in the Yogyakarta area.
\end{abstract}

Keywords: language perception, language attitude, language preservation

\section{PENDAHULUAN}

Fenomena pemakaian bahasa Jawa kian hari kian memprihatinkan. Masyarakat Jawa, khususnya yang berdomilisi di daerah perkotaan di wilayah Yogyakarta lebih banyak memilih pemakaian bahasa Indonesia dalam bahasa sehari-hari. Pemakaian bahasa Indonesia lebih dominan baik di lingkungan sekolah, lingkungan pekerjaan, maupun lingkungan rumah.

Kondisi semacam ini terlihat sangat mencolok, terutama di lingkungan keluarga yang orang tuanya berkarir. Anak-anak, terutama di lingkungan keluarga atau orang tua yang berkarir lebih dikenalkan bahasa Indonesia sebagai bahasa ibu oleh orang tuanya. Hal ini dipengaruhi oleh faktor kebiasaan. Terlebih di wilayah Yogyakarta, heterogonitasnya sangat menonjol, masyarakatnya berasal dari berbagai daerah maupun berbagai lapisan sosial ekonomi. Dengan demikian pemakaian bahasa Indonesia menjadi kebutuhan, dan lebih bersifat praktis. Tak mengherankan bila bahasa Jawa menjadi sesuatu yang asing di telinga sebagian masyarakat, khususnya di perkotaan.

Faktor globalisasi menjadi pemicu utamanya. Kondisi seperti di atas menjadi permasalahan tersendiri dalam hubungannya dengan pelestarian bahasa Jawa. Kondisi yang plural dalam masyarakat memang tidak bisa dihindari. Akan tetapi, eksistensi bahasa daerah juga perlu diperhatikan mengingat, bahasa daerah sebagai salah satu kekayaan budaya nasional, dan dalam bahasa tercermin budaya masyarakat penuturnya. Khusus untuk bahasa Jawa, di samping nilai budaya yang perlu dipertimbangkan, norma-norma yang ada dalam pemakaian bahasa ini bersentuhan langsung dengan karakter dan kepribadian masyarakat penuturnya. Sebagaimana yang dikemukakan oleh Sapir-Whorf yang menyatakan bahwa pandangan manusia tentang lingkungannya dapat ditentukan oleh bahasanya (Sumarsono, 
2007: 61). Artinya dalam budaya Jawa terdapat nilai-nilai filosofi yang harus dilestarikan, norma-norma kehidupan yang perlu dipertahankan.

Berpijak dari pemikiran di atas, berarti pergeseran pemakaian bahasa Jawa menjadi bahasa Indonesia di lingkungan masyarakat Jawa, perlu mendapat perhatian khusus. Bila fenomena ini dibiarkan, tidak menutup kemungkinan perkembangan dan pelestarian bahasa daerah (bahasa Jawa) mendekati titik kepunahan. Untuk memotret fenomena ini diperlukan kajian khusus, di mana potret pemakaian bahasa Jawa di masyarakat, khususnya di wilayah Yogyakarta dapat diketahui secara lengkap.

Salah satu parameter pelestarian pemakaian bahasa Jawa bisa dilihat dari diri penutur masyarakat tutur Jawa. Yang menjadi ukurannya bisa dimulai dari sikap bahasa masyarakat tuturnya. Sikap bahasa berkaitan langsung dengan sikap penuturnya dalam memilih dan menetapkan bahasa, apakah akan memakai bahasa Jawa sebagai bahasa ibu atau mengganti bahasa Jawa menjadi bahasa Indonesia. Bahkan, keputusan ini sampai berdampak pada penentuan pilihan apakah akan mempertahankan bahasa daerah sebagai bahasa ibu atau mengganti bahasa Indonesia sebagai bahasa ibu yang akan diajarkan pada anak-anaknya.

Berdasarkan latar belakang di atas, muncul gagasan untuk mengkaji fenomena tersebut. Karena fenomena ini cakupannya sangat luas, permasalahan akan difokuskan pada pemakaian bahasa Jawa di masyarakat tutur Jawa yang berlatar belakang pekerja (berkarir). Kemudian, difokuskan kembali pada penutur wanita yang berkarir. Dipilih wanita, karena wanita cenderung menjadi "pelopor" dalam perubahan, wanita juga lebih mengedepankan prestise dalam segala aspek, termasuk dalam berbahasa. Di samping itu, wanita juga merupakan kunci pola asuh bagi anakanaknya. Pola asuh yang dimaksud khususnya yang berhubungan dengan pola asuh pewarisan atau pengajaran bahasa, norma, dan perilaku. Dipilih wanita berkarir karena wanita karir cenderung memiliki ruang lingkup pergaulan yang luas, lingkungan karirnya menuntut pemakaian bahasa Indonesia sebagai bahasa persatuan mengingat lingkungan karir lebih bersifat heterogen.

\section{METODE PENELITIAN}

Penelitian ini merupakan penelitian survey. Penelitian survey sebenarnya lebih tepat merupakan salah satu jenis penelitian dari penelitian deskriptif (Cohen dan Nomion, 1982 via Sukardi 204: 193). Sejalan dengan tujuan penelitian survey, penelitian ini bertujuan mendeskripsikan situasi pemakaian bahasa Jawa di lingkungan keluarga wanita karir di wilayah Yogyakarta pada saat penelitian ini dilakukan. Tiga langkah penting dalam penelitian survey akan dipaparkan berikut ini.

Subjek dalam penelitian ini adalah wanita pekerja di wilayah Yogyakarta yang berbahasa ibu bahasa Jawa. Dipilihnya wanita pekerja di wilayah Yogyakarta ini karena setiap harinya mereka selalu berhubungan dengan bahasa Jawa dan bahasa Indonesia. Mengingat wilayah Yogyakarta memiliki heterogenitas masyarakat yang kompleks. Bahasa Jawa merupakan bahasa ibu dan biasa digunakan dalam situasi nonformal, sedangkan bahasa Indonesia selalu dipergunakan dalam situasi formal dan nonformal baik di dalam kantor, di luar kantor maupun dalam acara-acara resmi yang berhubungan dengan pekerjaan, seperti seminar, simposium, kerja praktek, pelayanan masyarakat dan sebagainya.

Dari seluruh populasi, yaitu wanita pekerja di wilayah Yogyakarta, diambil sampel yang melibatkan wanita 
dalam segala profesi. Teknik sampling dilakukan dengan sistem keterwakilan dengan memperhatikan profesi atau lingkungan kerja, lingkungan rumah, atau ranah keluarga, status sosial, pendidikan dan asal daerah. Lingkungan kerja yang dipilih sebagai sampel dalam penelitian ini dibatasi di wilayah Kota Yogyakarta dan Kabupaten Sleman. Daerah kerja tersebut dipilih karena lingkungan yang bersifat heterogen. Profesi-profesi wanita karir tersebut antara lain dosen, guru, customer servis, perawat, polisi, dokter, dan sebagainya. Dipilih enam puluh wanita karir sebagai responden dalam penelitian ini.

Instrumen yang digunakan dalam penelitian ini ialah kuesioner. Instrumen ini terdiri dari tiga bagian. Instrumen didahului dengan pengantar dari peneliti kepada responden. Selanjutnya, bagian I dimaksudkan untuk menjaring data pribadi responden. Bagian II untuk menjaring persepsi responden terhadap bahasa Jawa. Dibagian ini terdapat beberapa item pernyataan yang dimaksudkan untuk mengetahui persepsi responden terhadap bahasa Jawa. Digunakan skala Likert berdasarkan kesetujuan atau ketidaksetujuan responden atas sejumlah pertanyaan, yang masing-masing dan secara keseluruhan diasumsikan mencerminkan persepsi responden terhadap bahasa Jawa. Skala Likert memuat empat jawaban, yaitu: sangat tidak setuju, tidak setuju, Setuju, Sangat setuju.

Pengumpulan data dilakukan dengan membagi kuesioner kepada wanita karir secara langsung dan dikumpulkan secara langsung oleh peneliti tanpa melalui pos. Kuesioner yang berisi data hasil penelitian tersebut disebut dengan data kasar. Data kasar yang ada perlu diadministrasikan secara jelas untuk memudahkan analisis data. Langkah-langkah yang dilakukan dalam tahap ini, yaitu melakukan skorsing dan proses tabulasi. Setiap angket/kuesioner diskor dengan cara yang sama dan kriteria yang sama, hasilnya ditransfer dalam bentuk yang lebih ringkas dan mudah dilihat. Selanjutnya dilakukan analisis data dengan menggunakan prinsip analisis deskripsi.

\section{HASIL DAN PEMBAHASAN Persepsi Wanita Karir terhadap Bahasa Jawa}

Dari tabulasi angket yang ada diperoleh hasil 65\% wanita karir yang menyatakan sangat setuju terhadap pemertahanan bahasa Jawa sebagai warisan luhur, 32,5\% menyatakan setuju, dan 2,5\% menyatakan tidak setuju. Dari tabel 1 ini ditunjukkan bahwa persepsi masyarakat terhadap bahasa Jawa dan keinginan masyarakat untuk mempertahankan bahasa Jawa masih tinggi. Hal ini menunujukkan pula adanya sikap positif terhadap bahasa Jawa.

Dari tabulasi angket yang ada diperoleh angka $45 \%$ wanita karir menyatakan setuju dan $55 \%$ menyatakan sangat setuju. Hal ini menunjukkan bahwa hampir seluruh responden menyatakan bangga terhadap bahasa Jawa. Kebanggaan ini pula menunjukkan adanya sikap positif terhadap bahasa Jawa sebagai bagian dari kekayaan bahasa daerah di Indonesia.

Dari tabulasi yang ada diperoleh angka 35\% wanita karir menyatakan setuju, 62,5\% menyatakan sangat setuju dan 2,5\% menyatakan tidak setuju. Hal ini menunjukan bahwa masih banyak masyarakat dalam hal ini wanita karir yang memahami bahasa Jawa, dan masih menganggap bahasa Jawa memiliki nilai-nilai etika yang penting untuk dilestarikan dan diajarkan pada anakanaknya. Nilai-nilai etika dan estetika ini berkaitan dengan budi pekerti pada masyarakat penuturnya.

Dari tabulasi yang ada diperoleh angka $86 \%$ wanita karir menyatakan setuju bahwa bahasa Jawa mampu eksis 
di era globalisasi, 12,5\% bahkan menyatakan sangat setuju, dan hanya 1,5\% yang menyatakan tidak setuju. Hal ini mengindikasikan adanya sikap positif dari para penutur bahasa Jawa

Dari tabulasi yang ada, diperoleh angka 65\% wanita karir menyatakan sangat setuju, 30\% menyatakan setuju, dan hanya $5 \%$ yang menyatakan tidak setuju. Artinya, bahasa Jawa masih menduduki prioritas dalam hubungan sosial di masyarakat.

Dari tabulasi yang ada diperoleh angka $68,42 \%$ wanita karir menyatakan setuju, 28,94\% menyatakan sangat setuju, dan hanya 2,63 \% yang menyatakan tidak sejutu. Artinya, keinginan untuk melestarikan bahasa Jawa dengan cara digunakan pada generasi berikutnya menunjukkan antusias yang cukup bagus. Artinya pula, apabila bahasa Jawa digunakan dalam komunikasi seharihari berarti kemungkinan bahasa Jawa masih menjadi bahasa ibu bagi anakanaknya. Responden yang tidak menyatakan setuju ini memilih bahasa asing (bahasa Inggris) sebagai prioritas yang harus dipelajari dan digunakan anakanaknya.

Dari tabulasi yang ada diperoleh angka 57,5\% wanita karir menyatakan setuju, 40\% menyatakan sangat setuju, dan hanya 2,5\% yang menyatakan tidak setuju. Artinya, keinginan untuk melestarikan bahasa Jawa sebagai muatan lokal di sekolah juga tinggi. Dengan demikian, usaha pelestarian bahasa Jawa melalui jalur pendidikan juga didukung oleh masyarakat, khususnya di lingkungan perkotaan. Ketidaksetujuan ini muncul karena mereka berpikir bahwa bahasa Jawa di disekolah justru menjadi momok bagi anak-anaknya karena memang merasa asing dengan bahasa Jawa.

Dari tabulasi yang ada diperoleh angka 76,92\% wanita karir menyatakan setuju, dan 23,08\% menyatakan sangat setuju. Hal ini mengindikasikan bahwa masih diperlukannya pengembangan bahasa Jawa, khususnya kosa kata, mengingat perkembangan ilmu pengetahuan dan teknologi juga semakin berkembang pesat. Perkembangan bahasa Jawa harus mampu mengikuti perkembangan ilmu pengetahuan dan teknologi dengan cara mengembangkan kosa katanya, agar bahasa Jawa mampu eksis di era globalisasi ini.

Dari tabulasi yang ada diperoleh angka $62,5 \%$ wanita karir menyatakan setuju, 5\% menyatakan sangat setuju, $30 \%$ menyatakan tidak setuju, dan 2,5\% menyatakan sangat tidak setuju. Dari data ini menunjukkan bahwa terdapat hasil yang beragam dalam hal keantusiasan masyarakat dalam menyikapi bukubuku cerita berbahasa Jawa. Namun demikian, keingingan untuk membaca cerita dan mendengarkan berita dalam bahasa Jawa juga masih ada, khususnya di wilayah-wilayah perbatasan. Artinya, kehadiran radio dan TV lokal sebenarnya juga punya peranan penting dalam pelestarian bahasa Jawa ini.

Dari tabulasi yang ada diperoleh angka $66,66 \%$ wanita karir menyatakan setuju, 12,82\% menyatakan sangat setuju, 17,94\% menyatakan tidak setuju, dan $2,56 \%$ menyatakan sangat tidak setuju. Dari angka ini ditunjukkan bahwa penggunaan bahasa Jawa dalam organisasi sosial sebenarnya juga masih diperlukan, walaupun sudah dengan tercampur dengan bahasa Indonesia.

Persepsi wanita karir terhadap bahasa Jawa berdasarkan kelompok umur dipaparkan sebagai berikut ini. Dari tabulasi yang ada menunjukan bahwa seluruh responden dari usia 20- 50 tahun menyatakan setuju dan sangat setuju terhadap upaya pemertahana bahasa, hanya persentase tertinggi berada pada usia $20-30$ tahun, yaitu $18,42 \%$ menyatakan setuju dan $31,57 \%$ menyatakan sangat setuju. 
Dari tabulasi yang ada menunjukan bahwa seluruh responden dari usia 20- 50 tahun menyatakan setuju dan sangat setuju, artinya seluruh responden bangga terhadap bahasa Jawa. Persentase tertinggi berada pada usia 20-30 tahun, yaitu 26,31\% menyatakan setuju dan 23,68\% menyatakan sangat setuju.

Dari tabulasi yang ada menunjukan bahwa 98\% responden dari usia 2050 tahun menyatakan setuju dan sangat setuju, artinya seluruh responden menyadari nilai-nilai etika dan estetika dalam bahasa Jawa. Persentase tertinggi berada pada usia 30-40 tahun, yaitu $34,21 \%$ menyatakan setuju dan $18,91 \%$ menyatakan sangat setuju. Ketidaksetujuan justru muncul pada golongan tua (usia 40-50 tahun) sebanyak 2,7\%. Hal ini disinyalir karena ketidakpahaman mereka akan bahasa Jawa secara menyeluruh.

Dari tabulasi yang ada menunjukan bahwa 92\% responden dari usia 2050 tahun menyatakan setuju dan sangat setuju. Artinya, seluruh responden menyadari bahwa mereka memiliki sikap optimis terhadap eksistensi bahasa Jawa di era globalisasi. Persentase tertinggi berada pada usia $20-30 \%$ tahun, yaitu $34,21 \%$ menyatakan setuju dan 10,53\% menyatakan sangat setuju. Ketidaksetujuan muncul pada golongan usia 20-30 tahun sebanyak 7,89\%. Hal ini disinyalir karena pergaulan daa pengalaman mereka dalam berkomunikasi dengan masyarakat luas.

Dari tabulasi yang ada menunjukan bahwa sebanyak 95\% responden dari usia 20-50 tahun menyatakan setuju dan sangat setuju. Artinya, seluruh responden menyadari bahwa mereka mengakui peranan bahasa Jawa di era globalisasi dalam hubungannya dengan kegiatan sosial di masyarakat. Secara tidak langsung penggunaan bahasa Jawa masih diperlukan di kalangan masyarakat. Persentase tertinggi berada pada usia 20-30 tahun, yaitu sebanyak 31,57 \% menyatakan sangat setuju dan 18,42\% menyatakan setuju.

Dalam hubungannya dengan pewarisan bahasa Jawa, 62\% responden menyatakan setuju, tetapi $27,02 \%$ menyatakan tidak setuju. Ketidaksetujuan ini muncul pada golongan muda atau pasangan muda di usia 20-30 tahun. Golangan tengah, yaitu 30-40 tahun dan golongan tua 40-50 tahun menyatakan setuju dan sangat setuju jika anak-anak mereka belajar dan menggunakan bahasa Jawa. Ketidaksetujuan yang muncul pada golongan muda ini dipengaruhi oleh faktor globalisasi. Golongan ini menganggap bahasa Jawa tidak memiliki peranan penting ke depan, apalagi di era globalisasi. Bahasa yang diutamakan adalah bahasa Inggris sebagai bahasa internasional. Golongan ini memberi alasan bahwa mereka lebih bangga ketika anak-anaknya menggunakan bahasa Inggris.

Dari tabulasi di atas memperlihatkan bahwa 94,74\% responden menyatakan setuju dan sangat setuju terhadap muatan lokal bahasa Jawa sebagai mata pelajaran di sekolah yang berbahasa ibu bahasa Jawa. Hanya 5,26\% yang menyatakan tidak setuju. Ketidaksetujuan ini muncul pada golongan muda atau pasangan muda di usia 20-30 tahun. Golangan tengah yaitu 30-40 tahun dan golongan tua 40-50 tahun menyatakan setuju dan sangat setuju jika anak-anak mereka belajar dan menggunakan bahasa Jawa. Ketidaksetujuan yang muncul pada golongan muda ini dipengaruhi oleh faktor globalisasi. Golongan ini menganggap bahasa Jawa tidak memiliki peranan penting ke depan, apalagi di era globalisasi. Bahasa yang dipakai sehari-hari adalah bahasa Indonesia. Jadi, bahasa ibu anak-anaknya adalah bahasa Indonesia. Ketidaksetujuan muncul karena kesulitan anak-anak mereka belajar bahasa Jawa di sekolah. Kesulitan ini 
sendiri muncul karena ketidakbiasaan anak-anak ini menggunakan bahasa Jawa di rumah, sehingga bahasa Jawa dianggap barang asing yang sulit dipelajari.

Dari tabulasi yang ada memperlihatkan kesamaan pendapat, bahwa $100 \%$ responden menyatakan setuju dan sangat setuju untuk dilakukan pengembangan kosa kata bahasa Jawa, baik dari golongan muda (20-30 tahun), golongan menengah (30-40 tahun), dan golongan tua (40-50 tahun). Hal ini menunjukkan sikap positif para responden terhadap bahasa Jawa.

Dari tabulasi yang ada memperlihatkan kecenderungan keantusiasan para responden terhadap cerita dalam bahasa Jawa, kurang lebih 30\% responden menyatakan tidak setuju dan sangat tidak setuju terhadap cerita-cerita dan berita dalam bahasa Jawa. Angka 30\% itu muncul di kalangan muda (20-30 tahun). Hal ini mengindikasikan bahwa golongan muda sudah tidak senang untuk menikmati cerita-cerita dan berita dalam bahasa Jawa. Ketidaksenangan ini berangkat dari ketidakpahaman dalam mendengar dan membaca tulisan dalam bahasa Jawa, sehingga berita dan ceritanya juga sulit dipahami. Untuk golongan tengah dan golongan tua masih memiliki kecenderungan untuk membaca cerita-cerita dalam bahasa Jawa.

Dari tabulasi yang ada memperlihatkan kecenderungan pemakaian bahasa Indonesia dalam setiap perkumpulan di masyarakat, terutama di golongan muda dan menengah. Bahkan pada golongan muda kurang lebih 19\% responden menyatakan tidak setuju dan sangat tidak setuju, untuk golongan menengah hanya 2,7\% yang menyatakan tidak setuju. Ketidaksetujuan ini muncul pada responden yang berasal dari pemukiman di wilayah perumahan. Hal ini dapat dipahami karena wilayah perumahan di Yogyakarta berasal dari ber- bagai kalangan dan daerah asal, sehingga pluralitasnya sangat tinggi. Karena kondisi yang plural inilah, para penutur cenderung memilih menggunakan bahasa Indonesia dalam komunikasi di masyarakat, terlebih untuk komunikasi formal seperti arisan, paguyuban dan sebagainya.

\section{Pemilihan dan Penggunaan Bahasa oleh Wanita Karier}

Angket yang disebarkan untuk mengetahui penggunaan bahasa oleh wanita karir dianalisis secara keseluruhan dan berdasarkan kelompok umur. Hasil analisis angket penggunaan bahasa oleh wanita karir secara keseluruhan dijelaskan berikut ini.

Untuk berkomunikasi dengan suami mereka, wanita karir dalam penelitian ini sebagian besar, yaitu sebanyak $42,30 \%$, lebih banyak menggunakan bahasa Jawa daripada bahasa Indonesia. Alasan pemilihan bahasa Jawa ini dikarenakan wanita karir tersebut dan suaminya berasal/asli suku Jawa sehingga mereka terbiasa berkomunikasi dengan bahasa Jawa dari kecil. Komunikasi dengan bahasa Jawa bagi mereka dianggap lebih nyaman dan akrab. Bahasa Jawa yang digunakan dalam hal ini bisa bahasa Jawa ngoko maupun bahasa Jawa krama. Ada juga yang berbahasa Jawa ngoko, tetapi beberapa kosa kata tertentu berbahasa Jawa krama. Penggunaan yang krama ini untuk menghormati suami mereka. Sebanyak 23,07\% wanita karir ini bahkan selalu/ hampir selalu menggunakan bahasa Jawa untuk berkomunikasi dengan suami mereka. Alasannya tidak jauh berbeda dengan yang dikemukakan oleh wanita karir yang lebih memilih bahasa Jawa, yaitu suami istri orang Jawa sehingga dari awal berumah tangga mereka sudah berbahasa Jawa untuk berkomunikasi antarmereka.

Sementara itu, wanita karir yang 
selalu/ hampir selalu berbahasa Indonesia untuk berkomunikasi dengan suami sebanyak 15,38 \% lebih banyak menggunakan bahasa Indonesia daripada bahasa Jawa sebanyak 19,23\%. Alasan digunakan bahasa Indonesia ini antara lain suami wanita karir tersebut bukan orang suku Jawa dan suami istri sudah terbiasa komunikasi dengan bahasa Indonesia walaupun keduanya suku Jawa. Bagi kelompok ini bahasa Indonesia dianggap lebih mudah karena tidak ada tingkatan-tingkatannya.

Sejalan dengan komunikasi pada suami, untuk berkomunikasi dengan anak ternyata sebagian besar wanita karir juga masih menggunakan bahasa Jawa. Hal ini ditunjukkan dengan sebanyak 40,74\% lebih banyak menggunakan bahasa Jawa daripada bahasa Indonesia dan $14,81 \%$ selalu atau hampir selalu menggunakan bahasa Jawa. Mereka beralasan, anak sudah diajari bahasa Indonesia di sekolah sehingga tidak perlu diajari lagi di rumah. Selain itu, juga komunikasi dengan bahasa Jawa dirasakan lebih akrab dan santai karena memang orang tuanya berkomunikasi dengan bahasa Jawa. Yang tak kalah pentingnya ialah alasan supaya anak bisa bersikap santun kepada orang tuanya karena beberapa tingkatan dalam bahasa Jawa, walaupun sebetulnya kadang hanya kata-kata tertentu saja. Yang selalu berbahasa Jawa pada anaknya dikarenakan supaya anak terbiasa dengan bahasa Jawa sebagai bahasa daerahnya, dan mengajarkan unda usuk dalam bahasa Jawa.

Sebanyak 29,62\% wanita karir selalu/hampir selalu menggunakan bahasa Indonesia untuk berkomunikasi dengan anaknya. Beberapa alasan yang diberikan ialah karena wanita tersebut dibesarkan dengan menggunakan bahasa Indonesia, dan selanjutnya hal tersebut diaplikasikan pada anak. Mereka juga beranggapan anak lebih mudah mema- hami bahasa Indonesia (hal ini tentunya karena wanita karir ini memang sudah membiasakan diri berkomunikasi dengan bahasa Indonesia daripada bahasa Jawa pada anaknya). Selain itu, bahasa Indonesia lebih banyak digunakan di lingkungan sekolah dan masyarakat. Alasan-alasan ini tidak jauh berbeda dengan wanita karir yang memilih lebih banyak menggunakan bahasa Indonesia daripada bahasa Jawa. Sebanyak 11,11\% beralasan bahwa mereka tidak dibesarkan di Yogya dan sudah terbiasa berkomunikasi dengan bahasa Indonesia.

Penggunaan bahasa Indonesia dan bahasa Jawa hampir sama banyaknya untuk berkomunikasi dengan anak dipilih oleh 37,03 wanita karir. Mereka memilih hal ini karena lingkungan juga masih menggunakan bahasa Jawa selain bahasa Indonesia untuk berkomunikasi antarwarganya. Mereka juga berharap anak bisa berbahasa Jawa. Akan tetapi, mereka juga terkadang menggunakan bahasa Indonesia supaya anak bisa mengetahui bahasa Indonesia. Apalagi dari Anak dari TK sampai SD selalu menggunakan bahasa Indonesia sehingga anak kadang tidak mengerti bahasa Jawa.

Untuk berkomunikasi dengan pembantu separuh lebih wanita karir selalu/ hampir selalu menggunakan bahasa Jawa, yaitu sebanyak $60,02 \%$. Wanita karir ini memang menggunakan bahasa Jawa untuk berkomunikasi dengan suami dan anak dan dengan pembantu otomatis juga menggunakan bahasa Jawa terlebih pembantu juga suku Jawa. Ada juga yang disebabkan karena pembantu tidak bisa berbahasa Indonesia dan selalu berbahasa Jawa maka wanita karir menyesuaikan bahasa pembantu ini. Selain itu, juga keinginan untuk berunggah-ungguh dengan pembantu yang lebih tua atau mengajari unggahungguh dengan pembantu yang masih muda. 
Sementara itu, wanita karir yang selalu menggunakan bahasa Indonesia sebanyak 16,66\%. Penggunaan selalu bahasa Indonesia karena dengan suami dan anak wanita karir ini juga menggunakan bahasa Indonesia. Dalam situasi nonformal di masyarakat, bahasa Jawa masih berada pada fungsinya sebagai bahasa komunikasi. Wanita karir yang memilih selalu atau hampir selalu menggunakan bahasa Jawa sebanyak 33,33\% dan lebih banyak berbahasa Jawa daripada berbahasa Indonesia sebanyak 23,07 \%. Faktor lingkungan mendominasi pemilihan penggunaan bahasa Jawa ini. Mayoritas lingkungan wanita karir dalam lingkungan ini bersuku dan berbahasa Jawa. Selain itu, juga untuk menghormati tetangga, lebih komunikatif, dan lebih sopan.

Di pihak lain, lingkungan yang berasal dari berbagai daerah menjadikan wanita karir lebih memilih selalu/ hampir selalu menggunakan bahasa Indonesia daripada bahasa Jawa (15,38\%). Hal tersebut karena mereka tidak begitu mengerti bahasa Jawa dan terkadang tetangga kurang bisa bahasa Jawa. Sementara itu, yang lebih banyak menggunakan bahasa Indonesia daripada bahasa Jawa sebanyak 12,82\%. Alasan yang dikemukakan ialah kawatir salah bicara karena tidak paham unda usuk/ tingkatan bahasa Jawa kecuali dengan yang sudah dikenal dekat dan sebagian tetangga bersuku nonJawa. Yang menjawab bahasa Indonesia dan bahasa Jawa digunakan (hampir) sama banyaknya sebanyak 15,38 \%. Bila berkomunikasi dengan orang yang lebih tua mereka menggunakan bahasa Jawa,tetapi bila lebih muda bahasa indonesialah yang digunakan sebagai alat komunikasi. Selain itu, juga tetangga berasal dari berbagai suku ada suku Jawa dan suku nonJawa.

Untuk situasi komunikasi formal di masyarakat, bahasa Indonesia masih dipilih sebagai bahasa komunikasi oleh wanita karir dalam penelitian ini. Ini ditunjukkan dengan sebanyak 27,77\% selalu/ hampir selalu menggunakan bahasa Indonesia dan 25\% lebih banyak menggunakan bahasa Indonesia daripada bahasa Jawa. Situasi yang formal paling banyak dikemukakan sebagai alasan. Selain itu, juga dikarenakan faktor lingkungan masyarakat yang mengharuskan mereka berbahasa Jawa. Sebagian yang menjawab ini lingkungan mereka berasal dari berbagai daerah, Jawa dan nonJawa. Oleh karena itu, dipilihlah bahasa Indonesia yang sifatnya universal dan dimengerti semua orang, terlebih yang mayoritas lingkungan berbahasa nonJawa.

Untuk berkomunikasi dengan atasan, sebagian besar, yaitu sebanyak $60,52 \%$, menjawab selalu/ hampir selalu menggunakan bahasa Indonesia dan $21,05 \%$ lebih banyak menggunakan bahasa Indonesia daripada bahasa Jawa. Situasi formal menuntut mereka menggunakan bahasa ini. Selain itu, juga dikarenakan faktor suku/ asal atasan yang bukan berasal dari Jawa. Sementara itu yang menjawab bahasa Indonesia dan bahasa Jawa digunakan hampir sama banyaknya sebanyak 13,15\%. Wanita karir yang menjawab ini menyatakan bahwa dalam situasi resmi, misal rapat, digunakan bahasa Indonesia sedangkan saat berbincang santai maka digunakan bahasa Jawa. Yang menjawab lebih banyak menggunakan bahasa Jawa sebanyak 5,26\%. Faktor tempat kerja masih sangat bersifat kekeluargaan menjadi alasannya.

Berbeda halnya untuk berkomunikasi dengan teman sejawat. Sebagian besar wanita karir lebih memilih bahasa Jawa sebagai alat komunikasi. Hal ini ditunjukkan dengan sebanyak 36,84\% menjawab bahasa Indonesia dan bahasa Jawa digunakan hampir samabanyaknya dan $28,94 \%$ lebih banyak menggunakan 
bahasa Jawa daripada bahasa Indonesia. Faktor suku yang sama menjadi alasan utama pemilihan bahasa Jawa. Sebagian besar teman mereka berasal dari suku Jawa sehingga dirasa lebih dekat dan lebih akrab menggunakan bahasa bahasa ini. Akan tetapi, bila teman mereka berasal dari suku nonJawa maka mereka akan menggunakan bahasa Indonesia. Namun, dalam suasana rapat, bahasa Indonesialah yang tetap digunakan sebagai alat komunikasi antarmereka.

Dengan bawahan, ternyata seimbang antara yang memilih bahasa Indonesia dan bahasa Jawa sebagai alat komunikasi wanita karir ini. Sebanyak 21,87\% memilih selalu/ hamper selalu menggunakan bahasa Indonesia dan $21,87 \%$ lebih banyak menggunakan bahasa Indonesia daripada bahasa Jawa. Sebanyak 21,87\% memilih bahasa Indonesia dan bahasa Jawa digunakan hampir sama banyaknya dan 28,12\% lebih banyak menggunakan bahasa Jawa daripada bahasa Indonesia. Sisanya sebanyak $6,52 \%$ lebih banyak menggunakan bahasa Jawa daripada bahasa Indonesia. Dalam fungsi pelayanan, misalnya melayani/berkomunikasi dengan siswa, mahasiswa, pasien, wali murid, ataupun yang lainnya bahasa Indonesia lebih dipilih sebagai alat komunikasi. Jawaban selalu/ hampir selalu menggunakan bahasa Indonesia sebanyak 44,73\% dan lebih banyak menggunakan bahasa Indonesia daripada bahasa Jawa sebanyak 44,73\%. Hal ini berarti hampir $90 \%$ bahasa Indonesia dipilih sebagai fungsi ini. Situasi resmi dan sebagai bahasa perantara menjadi alasan pemilihan bahasa Indonesia ini. Bahasa Indonesia dianggap lebih mudah dipahami orang karena siswa atau mahasiswa atau yang dilayani lainnya berasal dari berbagai suku.

Bahasa Indonesia lebih dipilih untuk berkomunikasi dengan orang yang belum dikenal. Hal ini ditunjukkan de- ngan sebanyak 41,17\% selalu/ hampir selalu menggunakan bahasa Indonesia dan 32,35\% lebih banyak menggunakan bahasa Indonesia daripada bahasa Jawa. Alasan selalu digunakan bahasa Indonesia ini untuk berkomunikasi dengan orang yang belum dikenal karena wanita karir tersebut belum tahu apakah orang yang diajak bicara tersebut berasal dari suku Jawa ataukah tidak. Bila orang asing tersebut tidak berasal dari Jawa mereka beranggapan orang tersebut tidak bisa berbahasa Jawa. Untuk menjembatani komunikasi dengan orang asing maka diplihlah bahasa Indonesia dengan asumsi karena bahasa Indonesia sebagai bahasa persatuan maka banyak orang yang tahu bahasa tersebut sehingga bisa berkomunikasi antarmereka. Yang menjawab lebih banyak bahasa Indonesia karena mereka belum tahu kebiasaan orang tersebut dalam komunikasi dan kawatir bukan suku Jawa. Juga karena tidak bisa pakai Jawa karma.

Sebanyak $26,47 \%$ menyatakan bahwa bahasa Indonesia dan bahasa Jawa digunakan hampir sama banyaknya. Mereka melihat dulu, situas kondisi, dan asal orang yang belum dikenal tersebut. Kalau mereka pikir orang tersebut berasal dari bahasa Jawa dan bisa bahasa Jawa, maka dipilihlah komunikasi dengan bahasa Jawa. Namun, apabila tidak yakin, maka dipilihlah bahasa Indonesia.

Penggunaan bahasa oleh wanita karir juga dianalisis berdasarkan kelompok usia, yaitu kelompok usia 21 tahun - 30 tahun, 31 tahun-40 tahun, dan 41 tahun ke atas. Hasil analisis berturutturut disajikan berikut ini. Pada kelompok usia 21 tahun-30 tahun, bahasa Indonesia lebih dipilih sebagai alat untuk berkomunikasi dengan suami. Sebanyak 28,7\% menjawab selalu/ hampir selalu menggunakan bahasa Indonesia dan sebanyak 21,42\% lebih banyak meng- 
gunakan bahasa Indonesia daripada bahasa Jawa. Lain halnya dengan kelompok usia 31 tahun -40 tahun. Kelompok usia ini lebih banyak menggunakan bahasa Jawa daripada bahasa Indonesia (45,45\%) bahkan sebanyak $27,27 \%$ selalu / hampir selalu menggunakan bahasa Jawa. Kecenderungan untuk berbahasa Jawa pada suami juga ditunjukkan pada wanita karir kelompok usia 41 tahun ke atas. Hal ini ditunjukkan dengan $40 \%$ menjawab lebih banyak menggunakan bahasa Jawa daripada bahasa Indonesia dan $40 \%$ juga menjawab selalu/ hampir selalu menggunakan bahasa Jawa. Sisanya sebanyak $20 \%$ menjawab bahasa Indonesia dan bahasa Jawa digunakan hampir sama banyaknya.

Berkomunikasi dengan anak menggunakan bahasa Indonesia lebih dipilih wanita karir pada kelompok usia 21 tahun -30 tahun. Sebanyak 62,5\% selalu/hampir selalu menggunakan bahasa Indonesia dan sisanya sebanyak 37,5\% menggunakan bahasa Indonesia dan bahasa Jawa hampir sama banyaknya. Kelompok usia 31 tahun -40 tahun lebih cenderung berkomunikasi dengan anaknya menggunakan bahasa Jawa. Yang terakhir kelompok usia 41 tahun ke atas menggunakan bahasa Indonesia dan bahasa Jawa hampir sama banyaknya, yaitu sebanyak $60 \%$. Sebanyak 20\% memilih bahasa Indonesia, dan $20 \%$ selalu/hampir selalu bahasa Jawa.

Dengan pembantu, wanita karir kelompok usia 41 tahun ke atas sebanyak 100\% menggunakan lebih banyak bahasa Jawa daripada bahasa Indonesia. Hal serupa juga terjadi pada kelompok usia 31 tahun - 40 tahun yang menyatakan sebanyak $50 \%$ selalu/ hampir selalu menggunakan bahasa Jawa dan kelompok usia 21 tahun - 30 tahun, sebanyak $45,45 \%$ selalu/ hampir selalu menggunaan bahasa Jawa. Jadi, dengan pembantu semua kelompok umur lebih cenderung berkomunikasi dengan bahasa Jawa.

Dalam situasi komunikasi non formal di masyarakat, bahasa Jawa lebih dipilih sebagai sarana komunikasi pada tiga kelompok usia ini. Namun, pada kelompok usia 21 tahun - 30 tahun dan 31 tahun - 40 tahun mempunyai kecenderungan menggunakan bahasa Indonesia dengan alasan lingkungan berasal dari berbagai daerah. Sebanyak 60\% wanita kelompok usia 41 tahun ke atas selalu /hampir selalu menggunakan bahasa Jawa dalam berkomunikasi dengan masyarakat dalam suasana nonformal.

Berbeda halnya dalam situasi nonformal, dalam situasi komunikasi nonformal di masyarakat bahasa Indonesia tetap dijadikan sebagai alat untuk berkomunikasi. Hal ini berlaku untuk semua kelompok usia. Penggunaan bahasa Jawa masih tetap ada, tetapi untuk pembicaraan yang sifatnya santai saja (ngobrol).

Dengan beberapa alasan, antara lain atasan bukan orang Jawa dan situasi resmi, semua kelompok usia, menggunakan bahasa Indonesia untuk berkomunikasi dengan atasan di lingkungan/ tempat kerja.

Bilaberkomunikasidenganatasan, wanita karir kelompok usia 21 tahun30 tahun sebagian besar menggunakan bahasa Indonesia, tidak begitu halnya komunikasi dengan teman sejawat di lingkungan kerja. Mereka sebagian besar menggunakan bahasa Jawa dan bahasa Indonesia hampir sama banyaknya (5,89\%). Namun, untuk kelompok usia 31 tahun-40 tahun, dan 41 tahun ke atas lebih banyak menggunakan bahasa Jawa daripada bahasa Indonesia.

Komunikasi dengan bawahan untuk kelompok usia 21 tahun-30 tahun lebih banyak wanita kariryang menjawab bahasa Indonesia dan bahasa Jawa digunakan hampir sama banyaknya. 
Akan tetapi, untuk kelompok usia 31 tahun -40 tahun lebih banyak digunakan bahasa Jawa daripada bahasa Indonesia $(44,44 \%)$. Bahasa Jawa juga dipilih kelompuk usia 41 tahun ke atas untuk berkomunikasi dengan bawahan. Hal ini ditunjukkan dengan sebanyak 33,33\% lebih banyak menggunakan bahasa Indonesia daripada bahasa Jawa dan juga sebanyak 33,33\% selalu/hampir selalu menggunakan bahasa Jawa.

Bahasa yang digunakan dalam pelayanan lebih cenderung bahasa Indonesia dalam tiga kelompok usia. Selain itu, untuk berkomunikasi dengan orang yang belum dikenal, juga bahasa Indonesialah yang lebih dipilih sebagai alat komunikasi.

\section{Implikasi terhadap Pemertahanan Ba- hasa Jawa di Wilayah Yogyakarta}

Persepsi wanita karir di wilayah Yogyakarta terhadap bahasa Jawa sebenarnya masih bisa dikatakan sangat baik. Mereka masih menganggap bahasa Indonesia sebagai bahasa yang harus dipertahankan dan mempunyai arti penting dalam kehidupan sosial. Mereka juga setuju bila bahasa masih tetap dan terus digunakan dalam kehidupan sehari-hari, dijadikan muatan lokal di sekolah-sekolah dan dikembangkan lagi. Semua ini tentunya mempunyai arti yang sangat penting dalam pemertahanan bahasa Jawa, khususnya di Wilayah Yogyakarta. Hal tersebut dikarenakan wanita karir tersebut diharapkan akan meneruskan bahasa tersebut terhadap keturunan mereka atau anak-anak mereka. Setidaknya sikap bahasa yang positif terhadap bahasa Jawa ini diharapkan tidak melunturkan kebanggaan akan bahasa ini dan mereka masih bertekad menggunakan bahasa Jawa ini.

Namun, agaknya persepsi wanita karir terhadap bahasa Jawa ini tidak terus menjadikan mereka tetap konsisten menggunakan bahasa Jawa dalam situasi nonformal. Hal ini terlihat dari hasil penelitian terhadap pemilihan/ penggunaan bahasa oleh wanita karir di wilayah Yogyakarta. Sebenarnya pemakaian bahasa Jawa ini masih sangat merata, tetapi tetap ada pergeseran bahasa. Pergeseran-pergeseran terjadi di wilayah-wilayah pemukiman baru (perumahan), di mana situasi dan kondisi menuntut perubahan tersebut. Pluralitas yang ada mengharuskan penggunaan bahasa Jawa diganti menjadi bahasa Indonesia dengan alasan komunikasi yang efektif dan saling keterpahaman di antara penutur.

Berdasarkan usia, pada dasarnya semua lapisan masyarakat dengan segala usia menghendaki adanya pemertahanan bahasa Jawa, kesadaran untuk mempertahankan dan melestarikan juga muncul di semua usia. Untuk usia menengah dan tua, kesadaran ini juga diikuti oleh tindakan nyata, misalnya dengan menggunakan bahasa Jawa dalam perkumpulan resmi, mengajarkan anak-anak berbahasa Jawa, membaca dan mendengarkan cerita dan berita bahasa Jawa. Akan tetapi, di kalangan muda keinginan melestarikan bahasa Jawa tidak dibarengi dengan tindakan nyata, tidak ada dukungan terhadap pemakaian bahasa Jawa, baik secara teori maupun praktik. Hal ini bisa dipahami karena situasi dan kondisi pergaulan usia muda yang masih produktif ini sangatlah plural. Pluralitas dan globalisasi ini mendorong mereka memilih bahasa Indonesia sebagai sarana berkomunikasi. Itulah mengapa usaha pelestarian bahasa Jawa baik di lingkungan sekolah maupun rumah tidak didukung sepenuhnya oleh golongan ini. Meskipun di sisi lain, golongan ini tetap mendukung bahasa Jawa untuk dilestarikan bahkan dikembangkan khususnya kosa kata. Wacana pengembangan dan pelestariannya hanya menjadi sebuah pandangan tanpa diikuti usaha nyata. 


\section{SIMPULAN}

Berdasarkan hasil penelitian ini dapat disimpulkan hal-hal sebagai berikut. Pertama, persepsi wanita karir terhadap bahasa Jawa masih sangat baik. Wanita karir dalam penelitian ini sebagian besar setuju bahasa Jawa sebagai warisan luhur yang harus dipertahankan. Mereka juga masih mempunyai kebanggaan terhadap bahasa Jawa ini, dan setuju jika dikatakan di dalam bahasa Jawa terkandung nilai-nilai etika dan estetika yang harus diajarkan pada anakanaknya. Oleh karena itu, bahasa Jawa harus diajarkan di sekolah-sekolah dan lebih dikembangkan lagi. Kedua, persepsi yang positif terhadap bahasa Jawa ini juga didukung oleh pemilihan/ penggunaan bahasa oleh wanita karir dalam situasi komunikasi nonformal. Sebagian besar wanita karir dalam penelitian ini masih menggunakan bahasa Jawa untuk berkomunikasi di masyarakat dalam situasi nonformal, serta dengan teman sejawat di lingkungan kerja. Sementara itu, bahasa Indonesia digunakan untuk berkomunikasi dengan masyarakat dalam situasi formal, dengan atasan dan bawahan di lingkungan kerja, dalam fungi pelayanan (misal dengan pasien, siswa, mahasiswa, masyarakat), dan dengan orang yang belum dikenal. Ketiga, berdasarkan hal-hal di atas, dapat dinyatakan bahwa belum terjadi pergeseran bahasa yang berarti dalam situasi komunikasi nonformal dari bahasa Jawa ke bahasa Indonesia oleh wanita karir di wilayah Yogyakarta.

\section{UCAPAN TERIMA KASIH}

Artikel ini diangkat dari penelitian yang dilaksanakan pada tahun 2009 dengan anggaran DIPA FBS UNY. Uca- pan terima kasih disampaikan kepada DPP Penelitian FBS UNY yang telah mendanai penyelenggaraan penelitian, seminar proposal dan hasil penelitian. Selanjutnya ucapan terima kasih disampaikan kepada dua reviewer anonim yang telah membaca, mengoreksi dan memberi masukan terhadap artikel ini.

\section{DAFTAR PUSTAKA}

Chaer, Abdul \& Leonie Agustina. 2004. Sosiolinguistik: Perkenalan Awal. Jakarta: PT Asadi Mahasatya.

Ernawati. 2004. "Prihatin Bahasa Daerah" dalam Kedaulatan Rakyat, Senin 10 Mei 2004.

Fishman, J. A. 1972. Language and Nationalism: Two Integrative Essays. Rowley, M. A: Newury House.

Rian, Bambang. 2004." Bahasa Jawa Sarat Etika dan Moral" dalam Kedaulatan Rakyat, Selasa 11 Mei 2004.

Mardianto, Herry. 2004. “Bahasa Jawa di Tengah Arus Modernism" dalam Kedaulatan Rakyat, Rabu 12 Mei 2004.

Paina danSumarsono. 2004. Sosiolingistik. Yogyakarta: Sabda bekerja sama dengan Pustaka Pelajar

Sumarsono. 2007. Sosiolinguistik. Yogyakarta: Pustaka Pelajar.

Sukardi. 2004. Metodologi Penelitian Pendidikan: Kompetensi dan Praktisnya. Jakarta: Bumi Aksara.

Wijana, I Dewa Putu. 2002. “Kebijakan Bahasa dan Dinamika BahasaBahasa Daerah di Indonesia". Makalah dalam Seminar Nasional Dinamika Budaya Lokal dalam Wacana Global. Fakultas Ilmu Budaya Universitas Gajah Mada Yogyakarta. 